\title{
РОССИЙСКАЯ КОНСТИТУЦИЯ В ЗЕРКАЛЕ КИТАЙСКОЙ ЮРИДИЧЕСКОЙ НАУКИ
}

\begin{abstract}
Аннотация: Кюбилею Конституции РФ в КНР сформирован значительный корпус источников о российском конституиионализме. В иелом китайские ученые позитивно оценивают принятие Конституции РФ 1993 г., вместе стем отмечая в ней качества, присущие конституции переходного общества. Основное внимание китайских специалистов приковано к институтам кон-ституционного контроля и президента, причем если актуальность российско-го конституционного контроля обусловлена внутрикитайской дискуссией о возможности учреждения данного института в КНР, то российский президент интересует китайских ученых исключительно как юридический ключ к по-ниманию политической ситуации в России. Правовой статус Президента РФ, сформированный на основе модернизации реципированных западных образ-иов в соответствии с реальными историческими потребностями, называется ключевой особенностью конституционной системы органов государственной власти. Высокая оченка деятельности Конституционного Суда РФ заставляет китайских ученых пристально изучать условия, оказавшиеся необходимыли для формирования конституциионного контроля, с перспективой создания по-добного института в КНР. Прагматизм китайских исследователей позволяет определить относительную иенность различных институтов российского конституционного права, однако интерпретация китайских оченок должна проводиться с учетом специфики китайской правовой культуры.
\end{abstract}

Abstract: At the time of anniversary of the Russian Constitution a large corpus of sources on the Russian constitutionalism was formed in the People's Republic of China. Generally, the Chinese scientists give positive evaluations to the Constitution of 1993, however, noting the qualities typical of constitutions of transforming societies. The main focus of attention of the Chinese scholars resides with the institutions of the constitutional control and President, and while the topicality of the Russian constitutional control is due to the internal Chinese polemics on the possibility to introduce this institution in the People's Republic of China, the Russian president is of interest to the Chinese scientists as the legal key to the understanding of the political situation in Russia. The legal status of the President of the Russian Federation, which was formed on the basis of modernization of the Western models in accordance with the real historical needs is recognized as a key specific features of the constitutional structure of state government bodies. Highly positive evaluation of the activities of the Constitutional Court of the Russian Federation makes the Chinese scientists scrupulously study the conditions necessary for the formation of constitutional control due to the possible perspective of formation of a similar institution in the People's Republic of China. Pragmatic approach of the Chinese researchers allows to establish the comparative value of various institutions of Russian constitutional law, however, the interpretation of the Chinese evaluations should be done with due regard to the specific features of the Chinese culture.

Ключевые слова: Китай, конституиия, конституиионный контроль, президент, Россия, КНР, юридическая наука, разделение властей, Конституционный Суд, конституционное правосудие

Keywords: China, Constitution, constitutional control, President, Russia, the People's Republic of China, legal science, separation of powers, the Constitutional Court, constitutional justice.

декабре 2012 года китайские власти и научная общественность широко отметили тридцатилетие вступления в силу Конституции КНР. Проведение научных конференций и публичных лекций, издание научных трудов и другие акции имели своей целью привлечь всеобщее внимание к проблемам развития конституционного права. При этом традиционно широко были представлены сравнительные исследования конституционного права зарубежных государств, в ряду которых Россия занимает особое место. Год спустя двадцатилетний юбилей российской Конституции дает нам хороший повод «сверить часы» с китайскими исследователями и взглянуть на отражение нашей конституции в зеркале китайской юридической науки. Тем самым мы сможем не только увидеть российскую Конституцию со стороны (притом с неожиданной стороны!), но и сделать определенные выводы в отношении самих китайских наблюдателей и их государственно-правовой традиции.

Несмотря на общую увлеченность изучением американского, британского, германского, французского конституционализма, ряд китайских исследователей по-прежнему числят российское конституционное право в ряду объектов своего научного интереса. Подобное внимание обусловлено, во-первых, общностью истоков современной российской и китайской 
DOI: $10.7256 / 1811-9018.2013 .13 .9780$

При цитировании этой статьи сноска на dоі обязательна

\section{Право и политика $13(168) \cdot 2013$}

государственности, предопределившей наличие русского (советского) «следа» в большинстве китайских государственно-правовых институтов. Во-вторых, Россия продолжает играть решающую роль на международной арене, поэтому китайские исследователи стремятся глубже понимать и быть в состоянии прогнозировать развитие российского государственного строя и правопорядка. В-третьих, КНР, подобно России, находится на переходном этапе своего развития, так что опыт российского конституционализма имеет для Китая сугубо практическое значение, пусть иногда и в форме поучительного урока. ${ }^{1}$

Начало китайским юридическим исследованиям Конституции РФ было положено в 1999 г. с выходом из-под пера известного специалиста по советскому и российскому конституционному праву профессора Лю Сянвэня основательного труда «Конституционный строй Российской Федерации». ${ }^{2}$ После некоторого перерыва во второй половине 2000 -х годов исследовательский процесс активизировался и не снижает темпов в текущем десятилетии. За это время вышли монографии, посвященные Конституции РФ в целом ${ }^{3}$, в том числе основанные на методологии философии культуры ${ }^{4}$, а также отдельным институтам конституционного права ${ }^{5}$. Следует особенно отметить глубокую по содержанию совместную монографию шанхайского профессора Ян Синьюя и московских ученых С.М. Шахрая и А.Д. Хабибуллина «Право и конституция в переходных обществах» ${ }^{6}$, российское издание которой, к сожалению, не так доступно. Труды представителей традиционных центров изучения российского права, таких как Центр изучения российского права университета Чженьчжоу, руководимый профессором Лю Сянвэнем, Научно-исследовательский институт изучения России Хэйлунцзянского университета (Харбин),

\footnotetext{
${ }^{1}$ Ю Сяохун. Российский конституционный суд. Пекин: Изд-во общественных наук, 2009. С. 3.

2 Лю Сянвэнь, Сун Яфан. Конституционный строй Российской Федерации. Пекин: Юридическое изд-во, 1999.

${ }^{3}$ Хань Ягуан. Исследование российской Конституции. Пекин: Изд-во интеллектуальной собственности, 2012.

${ }^{4}$ Ян Чанъюй, Чень Фушэн. Трансформация российского общества и путь конституционализма. Пекин: Изд-во литературы по общественным наукам, 2009.

${ }^{5}$ Ю Сяохун. Российский конституционный суд. Пекин: Изд-во общественных наук, 2009; Лю Сянвэнь, Хань Бин, Ван Гуйюй. Институт конституционного правосудия в Российской Федерации. Пекин: Юридическое изд-во, 2012.

${ }^{6}$ Ян Синьюй, Шахрай С.М., Хабибуллин А.Д. Право и конституция в переходных обществах. Шанхай, Шанхайское изд-во «Саньлянь шудянь», 2006.
}

отличаются значительной глубиной и широким охватом русскоязычных источников. Определенный интерес к российскому конституционному праву присутствует и в китайской юридической периодике, причем встречаются даже опыты рецензирования ${ }^{7}$, однако большинство публикаций ограничиваются переложением китайской литературы и не обеспечивают оперативного информирования о развитии российского конституционного права. Вместе китайские исследования, посвященные российской Конституции, составляют достаточно объемный корпус источников, тематическая направленность и содержание которых способны сказать многое.

В целом китайские ученые позитивно оценивают принятие Конституции РФ 1993 г. «Принятие и вступление в силу Конституции РФ произошло в условиях глубоких преобразований социально-политического строя России. Конституция зафиксировала произошедшие в России общественно-политические изменения, закрепила государственное устройство и полномочия органов государственной власти, заложила основу для нового этапа стабильного политического развития общества и государства». ${ }^{8}$ «Конституция 1993 г. отразила фундаментальные изменения в общественной жизни, экономике, политике и идеологии, твердо закрепила права и свободы человека и гражданина, органично интегрировала их в структуру конституционного строя, обеспечила взаимосвязь института прав личности с принципом народного суверенитета и основами организации государственной власти, создала институты, нормы и процедуры, необходимые для обеспечения реализации прав и свобод человека и гражданина. Хотя новая конституция и не устранила раскол в обществе, не сняла остроту экономического кризиса, однако ее появление оказало стабилизирующее воздействие на государственные институты, способствовало преодолению перманентного политического кризиса». ${ }^{9}$

В то же время, в некоторых оценках нашли свое отражение сложные исторические условия, в которых принималась Конституция. Так, представители харбинской школы Ян Чанъюй и Чень Фушэн отмечают, что «российская Конституция представляет собой вынужденный выбор, который российская нация сделала

\footnotetext{
${ }^{7}$ Вэнь Хэнго. Эволюция российской Конституции под углом функционализма (Рецензия на: Авакьян С.А. Конституция России: природа, эволюция, современность. М.: РЮИД, Сашко, 2000) // Юридический вестник Пекинского университета. 2008. Вып. 9. № 1. С. 239-247.

${ }^{8}$ Син Гуанчэн и др. Российский парламент. Пекин: Изд-во «Хуася», 2001. C. 85.

${ }^{9}$ Ян Синьюй, Шахрай С.М., Хабибуллин А.Д. Указ. соч. С. 169, 173.
} 
в условиях кризиса переходного периода, ее основной целью была институциональная поддержка мер по выходу из кризиса и налаживанию новой жизни. Поэтому в развитии конституции и конституционализма преобладают рациональные соображения. Двадцатилетняя практика реализации положений Конституции в достаточной мере обнажила существенные издержки, возникшие в процессе аккультурации в российских условиях конституции, концептуально основанной на теориях западного конституционализма». ${ }^{10}$ Корифей китайской конституционно-правовой науки профессор Сюй Чундэ полагает, что «действующая Конституция РФ является конституцией переходного периода, в XXI веке ей предстоит дальнейшее развитие и совершенствование». ${ }^{11}$

Приведенные общие оценки основываются на характерном перечне основных особенностей Конституции 1993 г., сформулированных китайскими коллегами. Вопервых, указывается, что Конституция РФ закрепила статус России как независимого суверенного государства, исключив упоминания о положении союзной республики в рамках СССР. Во-вторых, утверждены типологические изменения российской государственности, выразившиеся в закреплении права частной собственности, принципа внеклассового народного суверенитета, обозначена перспектива преобразования Российской Федерации в буржуазное конституционное государство. В-третьих, примечательно придание китайскими специалистами особого значения закрепленной форме правления и ее основной особенности - институту Президента РФ. ${ }^{12}$ В то же время, по мнению профессора Ян Синьюя, «наиболее заметной новеллой Конституции 1993 г. стало разделение государственной власти на законодательную, исполнительную и судебную в целях недопущения присвоения всей полноты власти одним человеком или органом, а также обеспечения эффективного функционирования государства и предотвращения принятия ошибочных решений». ${ }^{13}$ Приведенный перечень особенностей определенно характеризует наблюдателей как представителей социалистической правовой традиции, а также закладывает основу для оживленной полемики о соотношении принципа разделения властей и института президента в российском конституционном праве, доныне продолжающейся в китайской научной среде.

\footnotetext{
${ }^{10}$ Ян Чанъюй, Чень Фушэн. Указ. соч. С. 133.

${ }^{11}$ См. Предисловие к: Лю Сянвэнь, Сун Яфан. Конституционный строй Российской Федерации. С. 2.

12 Лю Сянвэнь, Сун Яфан. Указ. соч. С. 24.

${ }^{13}$ Ян Синьюй, Шахрай С.М., Хабибуллин А.Д. Указ. соч. С. 172.
}

Еще более характерно распределение научного интереса по институтам российского конституционного права. Примечательно, что основное внимание китайских специалистов приковано к институтам конституционного контроля и президента. Конституционному контролю посвящены две специальные монографии, не считая обширных разделов в трудах общей тематики и многочисленных публикаций в научной периодике. Внимание юридической научной общественности к институту президента, являющееся отголоском всеобщего интереса к персонам трех российских президентов, нашло свое отражение в целом ряде научных статей и специальных глав в сочинениях о российском конституционализме. ${ }^{14}$ Характерны различные причины такого повышенного интереса: если актуальность российского конституционного контроля обусловлена необычайно оживленной внутрикитайской дискуссией о возможности введения данного института в условиях государственно-правового строя КНР, то российский президент интересует китайских ученых исключительно как юридический ключ к пониманию политической ситуации в России. Вслед за этим в рейтинге популярности «с большим отрывом» следуют институты прав человека, парламентаризма ${ }^{15}$, федеративного устройства и местного самоуправления, определенное внимание которым уделяется в периодической научной печати. Показанное распределение приоритетов позволяет говорить о таких особенностях китайского исследовательского подхода как утилитаризм при выборе объекта исследования и реализм в оценке относительной значимости элементов российского конституционного строя. Это предопределило концентрацию исследовательских усилий на изучении институтов конституционного контроля и президента, пусть даже в ущерб другим направлениям. Тем не менее, следует признать, что подобное сосредоточение научных усилий позволило не только сформировать достаточно полное представление об этих двух институтах, но и сделать несколько вполне оригинальных выводов.

\footnotetext{
${ }^{14}$ См. напр.: Лю Цинцай. Президент и Председатель Правительства в России: конституционный статус и разграничение полномочий // Исследования России, Средней Азии и Восточной Европы. 2008. № 8; Чжан Бо, Лю Сюэфэй. Правовое государство и политический авторитет в «эпоху Путина» // Экономика и культура окраины. 2005. № 7. С. 60-64; Ян Чанъюй, Чень Фушэн. Указ. соч. Гл. 4.

${ }^{15}$ Хотя институту парламентаризма и посвящена отдельная монография (см. Син Гуанчэн и др. Указ. соч.), ее появление объясняется изданием серии монографий, посвященных парламентам различных государств мира. Отсутствие в перечне авторов крупных специалистов по российскому праву, а в списке литературы - русскоязычных источников
} 
DOI: $10.7256 / 1811-9018.2013 .13 .9780$

При цитировании этой статьи сноска на доі обязательна

\section{Право и политика $13(168) \cdot 2013$}

Президент РФ по оценке китайских ученых является ядром системы разделения властей и государственного аппарата в целом, а его конституционно-правовой статус с чрезвычайно широкими полномочиями составляет главную отличительную черту системы органов государственной власти РФ. При этом китайские исследователи не избежали традиционного для российской юридической науки вопроса о форме республики в России. Если профессор Лю Сянвэнь указывает на закрепление полупрезидентской республики с элементами парламентского контроля по французскому образцу ${ }^{16}$, то другие исследователи говорят о наличии суперпрезидентской республики с положением президента над всеми ветвями власти ${ }^{17}$. Так или иначе, но большинство китайских специалистов сходятся в том, что конституционный статус Президента РФ сконструирован с учетом российской государственно-правовой традиции сильной авторитарной власти главы государства. «Правовой статус российского президента, выступающего ядром политического строя, сформировался в результате совпадения реальных потребностей и исторической культурной традиции в условиях национального кризиса и является примером эффективного и аксиологически обусловленного институционального выбора. Новаторство российского института президента в переходный период в сравнении с западными моделями состоит в том, что рецепция американских и французских образцов в специфических исторических условиях сопровождалась их модификацией в части расширения полномочий и повышения статуса президента».18

Именно в закрепленном Конституцией РФ 1993 г. высоком статусе и широких полномочиях Президента РФ китайские специалисты видят предпосылку успехов, достигнутых действующим Президентом РФ на своем посту. «В настоящее время российская экономика демонстрирует устойчивое развитие, международное влияние страны быстро растет, национальное могущество в целом повышается - эти благоприятные тенденции развития в определенном смысле подтверждают легитимность сильного президента. Сильный президент в течение переходного периода обеспечил надежную и функциональную основу для перехода к рынку и демократии». ${ }^{19}$ Вместе с тем, высказываются опасения, что по мере преодоления последствий кризиса 1990-х гг. положение Президента РФ над всеми ветвями власти, а

\footnotetext{
16 Лю Сянвэнь, Сун Яфан. Указ. соч. С. 26.

17 Чжан Бо, Лю Сюэфэй. Указ. соч. С. 61.

${ }^{18}$ Ян Чанъюй, Чень Фушэн. Указ. соч. С. 151.

19 Там же. С. 147.
}

также сделанная в переходный период ставка на личную харизму президента как на основание легитимности всего данного института может не выдержать столкновения с новыми реалиями формирующегося правового государства и гражданского общества.

В рамках системы разделения властей сильный президент оказывает влияние на другие ветви власти, в первую очередь на парламент. Как отмечают авторы монографии «Российский парламент»: «По мере распада советского строя значение представительных органов государства неуклонно снижалось, тогда как статус органов исполнительной власти, в особенности президента, неуклонно повышался. Согласно новой тенденции развития системы органов государственной власти, президент приобрел главенствующее положение в системе, тогда как парламент и судебные органы оказались в значительной зависимости от исполнительной власти и президента, практически утратив возможность самостоятельных действий». ${ }^{20}$ Таким образом, апеллируя к классической западной теории разделения властей, китайские ученые указывают на опасность закрепленного в Конституции РФ статуса Президента РФ для принципа разделения властей.

В то же время, по мнению китайских исследователей, реализация в Конституции РФ принципа разделения властей и стесненное положение Федерального Собрания в системе органов государственной власти привели к ряду негативных последствий. Во-первых, нижняя палата парламента (Государственная Дума) зачастую пассивно относится к законодательной работе, тормозя принятие внесенных правительством в рамках экономической реформы важных законопроектов, а в вопросах формирования правительства между Государственной Думой и Президентом неоднократно возникают противоречия, разногласия, вплоть до открытого противостояния. Во-вторых, Федеральное Собрание РФ утратило возможность прямого руководства представительными законодательными органами субъектов РФ. В-третьих, невозможность образования обеими палатами парламента общих постоянных органов (таких как президиум парламента) приводит к разногласиям и даже противостоянию между палатами..$^{21}$ Приводимые китайскими коллегами «недостатки» функционирования принципа разделения властей в высшей степени иллюстративны, так как фактически сводятся к дефициту взаимопонимания, взаимодействия и, в конечном счете, единства высших

\footnotetext{
${ }^{20}$ Син Гуанчэн и др. Указ. соч. С. 90.

${ }^{21}$ Там же. С. 95-98.
} 
органов государственной власти. Легко заметить, что все указанные китайскими коллегами проблемы устраняются в системах с единым высшим органом государственной власти, стоящим во главе иерархического государственного аппарата. Таким образом, если с позиций западной конституционной доктрины китайские ученые опасаются за сохранность принципа разделения властей, то когда дело доходит до реального функционирования системы разделения властей с ее неизбежными конфликтами, традиционные для китайской культуры представления о единстве власти и коммунистическая идеологическая подготовка вновь заставляют их чувствовать себя неуютно.

Вместе с тем, основное внимание китайских исследователей приковано к другому элементу системы разделения властей - судебной власти, в особенности, к конституционному правосудию. Конституционный контроль и конституционное правосудие как ядро комплекса средств охраны Конституции привлекает столь пристальное внимание потому, что по мере проведения правовой реформы в КНР проблемы эфемерности конституции, ее несоблюдения государственными и партийными органами, декларативного характера конституционных прав личности все более остро осознаются в научных и общественных кругах. Лейтмотивом исследовательских усилий китайских специалистов служит заголовок написанного корифеем китайской конституционно-правовой науки профессором Ху Цзиньгуаном предисловия к работе Ю Сяохун «Российский конституционный суд»: «Китаю также нужен конституционный контроль»22.

Утилитарность исследовательского подхода предопределила особый интерес китайских авторов к условиям, необходимым для создания института конституционного контроля. Так, отмечается, что на раннем этапе (в период распада СССР) основным идеологически мотивом создания конституционного надзора были широко пропагандировавшиеся ценности права и правового государства. Впоследствии теоретической основой формирования института конституционного контроля стало утверждение принципа разделения властей, происходившее на фоне отказа от «полновластия Советов». Одновременно с этим в Конституции РФ были закреплено положение о высшей юридической силе и прямом действии Конституции, ставшее непосредственным основанием для применения Конституции РФ в работе Конституционного Суда. Профессор Лю Сянвэнь отмечает, что «учреждение

${ }^{22}$ Ю Сяохун. Указ. соч. С. 1.
Конституционного Суда РФ было не одномоментным актом, но стало возможным лишь после созревания целого ряда условий. В то же время, российский опыт наглядно показывает, что избрание государством той или иной модели конституционного контроля (надзора) в конечном итоге определяется существующими в государстве историческими традициями, особенностями политического режима и правовой системы». ${ }^{23}$

Китайская оценка деятельности Конституционного Суда РФ традиционно высока, он рассматривается в качестве наиболее ценного и перспективного института российского конституционного права. Как отмечает исследовательница Ю Сяохун, «на протяжении истории своего существования Конституционный Суд РФ достиг значительных результатов в обеспечении прав человека и регламентации пределов государственной власти и представляется наиболее эффективным институтом в этой области». ${ }^{24}$ При этом основной проблемой функционирования конституционного контроля называется неоднозначная ситуация с исполнением актов Конституционного Суда РФ. Именно позитивные изменения, произошедшие в этой сфере после избрания В.В. Путина Президентом РФ в связи с начатой им федеративной реформой и встраиванием Конституционного Суда РФ в систему обеспечения соответствия законодательства субъектов РФ Конституции РФ и федеральному законодательству, позволили профессору Лю Сянвэню говорить о возрождении авторитета Конституционного Суда после периода забвения 19922003 гг., отмеченного повсеместными нарушениями федерального законодательства. ${ }^{25}$ Данный вывод представляется несколько неожиданным и вместе с тем иллюстративным, так как возрождение конституционного правосудия в китайской интерпретации оказалось связанным с включением Конституционного Суда в систему органов и институтов обеспечения единства «вертикали власти». Представляется, что основанием такой позиции является традиционное китайское восприятие принципов федерализма и разделения властей как проявлений различной степени анархии, а вертикального и горизонтального единства власти - как свидетельства возрождения государственных институтов.

Тем не менее, несмотря на высокие оценки института конституционного контроля, китайские ученые делают реалистичный вывод о невозможности его введения в КНР в связи с отсутствием необходимых условий. Во-первых,

\footnotetext{
${ }^{23}$ Лю Сянвэнь, Ван Гуйюй. Указ. соч. С. 337.

${ }^{24}$ Ю Сяохун. Указ. соч. С. 174, 215.

25 Лю Сянвэнь, Ван Гуйюй. Указ. соч. С. 335.
} 
DOI: $10.7256 / 1811-9018.2013 .13 .9780$

При цитировании этой статьи сноска на доі обязательна

\section{Право и политика $13(168) \cdot 2013$}

принципы верховенства представительных органов и демократического централизма не позволяют говорить о разделении властей. Во-вторых, Высшее Собрание Народных Представителей КНР формируется на выборной основе и выражает волю народа, в связи с чем контроль конституционности его решений представляется нелегитимным. Положение усугубляется отсутствием в КНР традиции независимости судебных органов и низким качеством судейского корпуса, не позволяющим надеяться на успешное решение задач конституционного контроля. В-третьих, Конституция КНР хотя и обладает высшей юридической силой, но не имеет качества прямого действия, в связи с чем не может служить основой для судебных решений судов общей юрисдикции. ${ }^{26}$

Подводя итог, следует иметь в виду, что принимая комплименты или критические замечания от китайских исследователей в адрес российской Конституции, мы вступаем в диалог с представителями сложной правовой культуры, складывающейся из традиционного китайского правосознания, коммунистической политикоправовой традиции и воспринимаемой в последнее время научными кругами КНР западной конституционной доктрины. В этой связи некоторые выводы китайских специалистов о российском конституционализме носят противоречивый характер, отражая сложный внутрикитайский научно-правовой и политический дискурс. На примере различного в своей мотивации интереса китайских ученых к институтам конституционного контроля и Президента РФ мы можем обнаружить наличие в российском конституционном праве как институтов, ценных своей функциональностью в специфических российских условиях (например, сильной президентской власти), так и тех, ценность которых определяется вкладом в развитие реального конституционализма (соответственно, конституционный контроль). Если институты первого рода исследуются китайской наукой с ограниченной целью - достичь понимания российской политической реальности, то в отношении второй разновидности всерьез обсуждается возможность их учета в процессе модернизации китайского государственного строя. Для развития российского конституционализма имеют значение обе «разновидности» институтов, вопрос лишь в оптимальном их соотношении, при котором традиционный институт сильной президентской власти содействовал бы повышению авторитета конституционного правосудия, а не наоборот.

Кроме того, при определении динамики развития российского конституционализма и реализации его основ-

${ }^{26}$ Там же. С. 338. ных принципов также следует взвешенно воспринимать оценки зарубежных, в том числе китайских, специалистов. Поэтому «конфликтность», «разобщенность», «отсутствие единства» между различными ветвями и уровнями власти не всегда говорит о неблагополучии конституционного порядка, но может оказаться неизбежной особенностью функционирования принципов разделения властей и федерализма, в то время как укрепление единства и взаимодействия органов власти также не обязательно свидетельствует о налаживании конституционного быта.

\section{Библиография:}

1. Вэнь, Хэнго. Эволюция российской Конституции под углом функционализма (Рецензия на: Авакьян С.А. Конституция России: природа, эволюция, современность. М.: РЮИД, Сашко, 2000) [Текст] / Хэнго Вэнь // Юридический вестник Пекинского университета. - 2008. - Вып. 9. - № 1. - С, 239-247.

2. Лю, Сянвэнь. Конституционный строй Российской Федерации [Текст] / Сянвэнь Лю, Яфан Сун. Пекин: Юридическое изд-во, 1999. - 500 с. -4000 экз. - ISBN 7-0536-2926-6.

3. Лю, Сянвэнь. Институт конституционного правосудия в Российской Федерации [Текст] / Сянвэнь Лю, Бин Хань, Гуйюй Ван. - Пекин: Юридическое изд-во, 2012. - 350 с. - Библиогр.: с. 341-346. - ISBN 978-7-5118-4071-4.

4. Лю, Цинцай. Президент и Председатель Правительства в России: конституционный статус и разграничение полномочий [Текст] / Цинцай Лю // Исследования России, Средней Азии и Восточной Европы. - 2008. - № 8. - С. 34-40.

5. Син, Гуанчэн. Российский парламент обществах [Текст] / Гуанчен Син, Дэли Пань, Яцзюн Ли. - Пекин: Изд-во «Хуася», 2001. - 270 с. - ISBN 7-5080-2449-4.

6. Хань, Ягуан. Исследование российской Конституции [Текст] / Ягуан Хань. - Пекин: Изд-во интеллектуальной собственности, 2012. - 215 с. - ISBN 978-7-5130-1220-1.

7. Чжан, Бо. Правовое государство и политический авторитет в «эпоху Путина» [Текст] / Бо Чжан, Сюэфэй Лю // Экономика и культура окраины. 2005. - № 7. - С. 60-64.

8. Ю, Сяохун. Российский конституционный суд [Текст] / Сяохун Ю. - Пекин: Изд-во общественных наук, 2009. - 230 с. - Библиогр.: с. 218-228. - ISBN 978-7-5004-8080-8. 
DOI: $10.7256 / 1811-9018.2013 .13 .9780$

При цитировании этой статьи сноска на dоі обязательна

Правоведение

9. Ян, Синьюй. Право и конституция в переходных обществах [Текст] / Синьюй Ян, С.М. Шахрай, А.Д. Хабибуллин. - Шанхай: Шанхайское изд-во «Саньлянь шудянь», 2006. - 395 с. - ISBN 7-54262314-1.

10. Ян, Чанъюй. Трансформация российского общества и путь конституционализма [Текст] / Чанъюй Ян, Фушэн Чень. - Пекин: Изд-во литературы по общественным наукам, 2009. - 255 с. - Библиогр.: c. 241-250. - ISBN 978-7-5097-0616-9.

\section{References (transliteration):}

1. Ven', Khengo. Evolyutsiya rossiiskoi Konstitutsii pod uglom funktsionalizma (Retsenziya na: Avak'yan S.A. Konstitutsiya Rossii: priroda, evolyutsiya, sovremennost'. M.: RYuID, Sashko, 2000) [Tekst] / Khengo Ven' // Yuridicheskii vestnik Pekinskogo universiteta. - 2008. - Vyp. 9. - № 1. - S, 239-247.

2. Lyu, Syanven'. Konstitutsionnyi stroi Rossiiskoi Federatsii [Tekst] / Syanven' Lyu, Yafan Sun. - Pekin: Yuridicheskoe izd-vo, 1999. - 500 s. -4000 ekz. ISBN 7-0536-2926-6.

3. Lyu, Syanven'. Institut konstitutsionnogo pravosudiya v Rossiiskoi Federatsii [Tekst] / Syanven' Lyu, Bin Khan', Guiyui Van. - Pekin: Yuridicheskoe izd-vo, 2012. - 350 s. - Bibliogr.: s. 341-346. - ISBN 978-75118-4071-4.
4. Lyu, Tsintsai. Prezident i Predsedatel' Pravitel'stva v Rossii: konstitutsionnyi status i razgranichenie polnomochii [Tekst] / Tsintsai Lyu // Issledovaniya Rossii, Srednei Azii i Vostochnoi Evropy. - 2008. № 8. - S. 34-40.

5. Sin, Guanchen. Rossiiskii parlament obshchestvakh [Tekst] / Guanchen Sin, Deli Pan', Yatszyun Li. Pekin: Izd-vo «Khuasya», 2001. - 270 s. - ISBN 7-5080-2449-4.

6. Khan', Yaguan. Issledovanie rossiiskoi Konstitutsii [Tekst] / Yaguan Khan'. - Pekin: Izd-vo intellektual'noi sobstvennosti, 2012. - 215 s. - ISBN 978-7-5130-1220-1.

7. Chzhan, Bo. Pravovoe gosudarstvo i politicheskii avtoritet v «epokhu Putina» [Tekst] / Bo Chzhan, Syuefei Lyu // Ekonomika i kul'tura okrainy. - 2005. - № 7. - S. 60-64.

8. Yu, Syaokhun. Rossiiskii konstitutsionnyi sud [Tekst] / Syaokhun Yu. - Pekin: Izd-vo obshchestvennykh nauk, 2009. - 230 s. - Bibliogr.: s. 218-228. - ISBN 978-7-5004-8080-8.

9. Yan, Sin'yui. Pravo i konstitutsiya v perekhodnykh obshchestvakh [Tekst] / Sin'yui Yan, S.M. Shakhrai, A.D. Khabibullin. - Shankhai: Shankhaiskoe izd-vo «San’lyan' shudyan'», 2006. - 395 s. - ISBN 7-5426-2314-1.

10. Yan, Chan"yui. Transformatsiya rossiiskogo obshchestva i put' konstitutsionalizma [Tekst] / Chan"yui Yan, Fushen Chen'. - Pekin: Izd-vo literatury po obshchestvennym naukam, 2009. - 255 s. - Bibliogr.: s. 241-250. - ISBN 978-7-5097-0616-9. 